\title{
SUBJECTS IN ACEHNESE AND THE NATURE OF THE PASSIVE
}

\author{
JULIE ANNE LEGATE \\ University of Pennsylvania
}

\begin{abstract}
This article reexamines a controversial construction in Acehnese (Lawler 1977 versus Durie 1988). I demonstrate that the construction is a passive, even though a verbal prefix bears the features of the agent rather than the surface subject. I analyze the prefix as a morphological realization of the functional head that introduces the external argument; the features borne by this head are not agreement, but rather interpretable features that restrict the external argument position. Important consequences are that Acehnese does not counterexemplify the universality of grammatical relations (contra Durie 1988 and subsequent), and that Acehnese provides clear morphological evidence for the presence in passives of the functional head that introduces the external argument.*
\end{abstract}

Keywords: Acehnese, passive, agreement, voice, grammatical relations

1. Introduction. Acehnese came to the attention of linguistic researchers with Lawler's 1977 claim that the language exhibits a passive in which, surprisingly, it is the agent, not the surface subject, that triggers subject agreement. ${ }^{1}$ Due to this unusual property, in the subsequent decade Acehnese was often cited as compelling evidence for a demotion analysis of the passive, whereby the agent originates in subject position, triggers subject agreement, and subsequently demotes to adjunct status (see, for example, Perlmutter 1982, Baker 1985, Dryer 1986). However, Durie's 1988 reply in these pages argued that Lawler had made fundamental mistakes in translation and analysis of the data, and that the construction in question is not a passive. Durie's (1985) grammar of Acehnese lays out his own analysis: the construction consists of a topicalized theme with an ergative-marked agent. Acehnese thereafter has largely been cited as a language that lacks a grammatical subject, thus providing evidence that grammatical functions are not universal (Durie 1987, Dixon 1994, Van Valin \& LaPolla 1997). ${ }^{2}$

In this article, I reexamine the construction at the center of the debate between Lawler and Durie. I argue that despite Lawler's errors, the analysis of the construction

* Thank you to my Acehnese consultants Saiful Mahdi, Dian Rubianty, Abdul Jalil, Cut Zahara, and Muhammad Zaki for teaching me about their language. Saiful speaks a mixture of the Pidie and Banda Aceh dialects; Dian speaks the Banda Aceh dialect; Abdul and Cut speak the North Aceh dialect; Zaki speaks a variety of the Banda Aceh dialect spoken in Lho-nga. Some of the data were collected in conjunction with two field methods classes, one at the University of Cornell and the other at the University of Pennsylvania; I thank my co-teachers, Abby Cohn and Gene Buckley, and the participants in both classes. This work was partially supported by a grant from the Mario Einaudi Center for International Studies, Cornell University, held jointly by me and Abby Cohn. Thank you to Heidi Harley, Howard Lasnik, and the audiences at the East and Southeast Asian Linguistics Discussion Group at Cornell University (2007), the 39th meeting of the North East Linguistic Society at Cornell University (2008), Austronesian Formal Linguistics Association 17 at Stony Brook University (2010), GLOW in Asia 8 in Beijing (2010), the 41st meeting of the North East Linguistic Society at the University of Pennsylvania (2010), and at the linguistics colloquium series at UCLA (2008), Rutgers University (2010), the University of Delaware (2011), Georgetown University (2011), Utrecht University (2012), and the University of York (2012) for comments and discussion on (earlier versions of) (parts of) this work. Thank you also to two anonymous Language referees for comments that led to improvements throughout.

${ }^{1}$ Acehnese, also known as Aceh, Atjeh, Atjehnese, Achinese, Achenese, and Achehnese, is an Austronesian language of the Malayo-Polynesian branch spoken by approximately three million people, mainly in the coastal area of Aceh Province, the northern tip of Sumatra, Indonesia.

${ }^{2}$ Lawler's own position on Acehnese evolved; already in the 1977 paper, his first footnote disavows the relational grammar framework he uses for analysis of the construction as a PASSIVE, and in his 1988 reply to Durie, he concludes that Acehnese can be adequately described both with the notion SUBJECT (as in Asyik 1987) and without it (as in Durie 1985). 
as a passive is correct (see also Asyik 1982, which assumes the passive analysis). Upon close examination of the apparent agreement prefix on the verb, I determine that rather than being true agreement, it consists of a pronunciation of the functional head that introduces the thematic subject, which I refer to as $v$.

The Acehnese discussion in this article has two important broader implications. First, the Acehnese case has important theoretical consequences for our understanding of the passive. Acehnese provides striking evidence for the proposal that the external argument introducing $v$ is present in passives (e.g. Marantz 2001, Embick 2004, Landau 2009). ${ }^{3}$ This head is morphologically realized in Acehnese passives, and is realized in such a way that its function is transparent - through the features of the external argument position that it introduces.

Second, the Acehnese case is methodologically instructive. Acehnese is frequently confidently cited as a language with no evidence for grammatical relations, or, relatedly, as a language in which the object of an unaccusative patterns as a surface object (instead of as a surface subject; see e.g. Dixon 1994, Tomasello 1995:139, Bittner \& Hale 1996:45-47, Van Valin \& LaPolla 1997, Newmeyer 2002:73, etc.). And yet, the claim is entirely based on the work of a single researcher, Mark Durie, whose work dates from the 1980s. Before the current article, the Acehnese data had never been reexamined using the battery of established syntactic tests that we now have at our disposal. And the result of applying these tests is a complete reversal of the import of Acehnese-Acehnese is revealed to exhibit grammatical functions after all, and so is consistent with the universality of grammatical functions, rather than counterexemplifying it. Specifically, there is evidence in Acehnese not only for a thematic subject position identified with the specifier of $v \mathrm{P}$, but also for a grammatical subject position, identified with the specifier of IP; ${ }^{4}$ I provide a number of arguments that the thematic object of a passive raises to become the grammatical subject (in $\S \S 3$ and 4.1). Pursuing the moral further, even though Lawler was correct in analyzing the relevant Acehnese construction as a passive, not only did he have insufficient arguments for doing so (hence Durie's rejoinder), but he also could not have arrived at the analysis proposed in this article $-v$ as a functional category would not be adopted for another twenty years. The Acehnese case then underlines the need for reevaluating theoretical and typological claims based on data from understudied languages that have not been investigated using modern syntactic tools, rather than simply citing and reciting the inadequate data.

I begin the reexamination of the Acehnese data in the next section with an outline of the construction in question.

2. The Le-COnStRUCtion. At the center of the debate is the alternation between la and $1 b .^{5}$

\footnotetext{
${ }^{3}$ The Acehnese data provide additional differentiation among analyses. For example, Collins (2005) also proposes that $v$ is present in passives, but claims that the thematic subject is in fact present in the specifier of $v \mathrm{P}$, either as a null $\mathrm{PRO}_{A R B}$ or as the overt DP previously thought to be embedded in a by-phrase (thus the $b y$ phrase not being a prepositional phrase at all). My data are not compatible with such an analysis. We see in $\S 5$ evidence that the lé-phrase patterns as a prepositional phrase in the passive, in contrast with an in-situ agent in the object voice. See Legate $2010 \mathrm{~b}$ for further discussion of the contrast between passive and object voice. When the $b y$-phrase is absent, the prefix continues to register specific features of the agent; thus there cannot be a thematic subject $\mathrm{PRO}_{A R B}$, nor can there be a thematic subject pro, since the passive without the $b y$-phrase is not pronominal either for the interpretation or for binding (see §5).

${ }^{4}$ Unlike English, filling this position appears to be nonobligatory; see examples 4 and 71 , and n. 39 .

${ }^{5}$ Unreferenced data are from my consultant notes. Acehnese examples are written largely following the orthography of Daud \& Durie 1999, and ignore the minor phonetic details of dialectal differences in pronunciation among my consultants. However, different spellings of Acehnese forms represent (dialectal) pronun-
} 
(1) a. Uleue nyan di-kap lôn. snake DEM 3.FAM-bite 1SG

'The snake bit me.'

b. Lôn di-kap lé uleue nyan.

1SG 3.FAM-bite LE snake DEM

'I was bitten by the snake.'

On one analysis, $1 \mathrm{a}$ is an active clause, and the LE-construction in $1 \mathrm{~b}$ is the passive alternate. The agent in the LE-construction is in a prepositional phrase, like the $b y$-phrase in English, and lé is properly glossed as by and compared to the Indonesian cognate oleh. On the other analysis (advocated by Durie, e.g. Durie 1985), the LE-construction is a theme-topic construction, and lé is identified as an ergative case marker; 1a, in contrast, is analyzed as an agent-topic construction, the ergative case marker being omitted when the agent is topicalized. Crucially, notice that the verbal prefix $d i$ - in $1 \mathrm{~b}$ realizes the third-person familiar features of the agent rather than the first-person features of the theme. Replacing this prefix with lon-, which realizes features of the theme, results in ungrammaticality.

(2) *Lôn lôn-kap lé uleue nyan. 1SG $1 \mathrm{SG}$-bite LE snake DEM

'I was bitten by the snake.'

Furthermore, this pattern is not dependent on this particular constellation of features, but is entirely general. The prefix tracks the person and politeness features of the agent.

(3) a. Aneuk miet nyan meu-tingkue lé kamoe. child small DEM 1.EXCL-carry LE 1.EXCL

'The child is carried by us.'

b. Aneuk miet nyan neu-tingkue lé droeneuh. child small DEM 2.POL-carry LE 2.POL

'The child is carried by you.'

c. Aneuk miet nyan geu-tingkue lé gopnyan. child small DEM 3.POL-carry LE 3.POL

'The child is carried by him/her.'

In addition to the agreement morphology, there are two properties that appear to lend support to the notion that the initial DP is a topic. First, the initial DP in both constructions must be old information (Durie 1985:192). For example, indefinite subjects are expressed through an existential construction with the initial DP position left empty. ${ }^{6}$

(4) a. Na ureueng nyang peu-beukah mangkok. EXIST person COMP CAUS-break bowl

'Someone broke the bowl.' ('There is a person who broke the bowl.')

b. Peue ${ }^{7} *$ (na) ureueng nyang ka taguen sie?

Q.COMP EXIST person COMP PERF cook meat

'Did anyone cook the meat?' ('Is there a person who cooked the meat?')

ciation differences and have been retained from the original publications in cited data. Abbreviations used in the glosses are as follows: CAUS: causative, COMP: complementizer, DEM: demonstrative, EXCL: exclusive, FAM: familiar, HORT: hortative, PERF: perfective, POL: polite, PROG: progressive. Acehnese does not exhibit tense marking. The tenses used in the translations are those provided when the data were collected; other tense translations are possible.

${ }^{6}$ Other quantificational DPs are allowed in the initial position; see $\S 4.1$.

${ }^{7}$ The question complementizer peue is also the wH-word 'what'. 
Second, it is not possible to topicalize a DP in front of the initial DP, ${ }^{8}$ which could be taken as a constraint against multiple DP topicalization.

(5) a. *Ibrahim dokto ka geu-peu-ubat.

Ibrahim doctor PERF 3.POL-CAUS-medicine

'The doctor treated Ibrahim.'

b. *Lôn asèe ka di-kap baroe.

1SG dog PERF 3.FAM-bite yesterday

'The dog bit me yesterday.'

Notice crucially that in these examples, the initial DP is in its standard position above any negation/modal/aspectual particles, and the verb is prefixed. As discussed in $\S 4.2$, there is an additional nonactive construction in Acehnese, which I term OBJECT VOICE, wherein the thematic subject remains in its $\theta$-position below negation $/$ modal $/$ aspectual particles, ${ }^{9}$ the verb is unprefixed, and the object may raise to the initial DP position. ${ }^{10}$ Thus, in contrast with 5, 6 is grammatical as an object voice construction.

(6) Lôn uleue nyan kap.

1SG snake DEM bite

'The snake bit me.'

I suspect that the restriction against $\mathrm{A}^{\prime}$-movement of a $\mathrm{DP}$ over the initial $\mathrm{DP}^{11}$ is a remnant of an earlier diachronic stage in which the initial DP was indeed a topic (see Wolff 1996), but I do not provide a synchronic analysis here. ${ }^{12}$ I do note, however, that the initial DP does not seem to occupy a topic position high in the left periphery of the clause. For example, it follows the wH-phrase, rather than preceding it as would be expected of a topic (see Rizzi 1997, Benincà 2001, Benincà \& Poletto 2004, and subsequent).

(7) a. Dari soe Zaki pinjam glah?

from who Zaki borrow glass

'From whom did Zaki borrow the glass?'

b. Pajan Fatimah geu-kalon Ibrahim?

when Fatimah 3.POL-see Ibrahim

'When did Fatimah see Ibrahim?'

Lawler's (1977) passive analysis of the LE-construction and Durie's opposing topicalization plus ergative case analysis make several testable predictions for the behavior of this construction. Regarding the raised object, a passive analysis predicts that this DP will show properties of an A-position, whereas a topicalization analysis predicts that it

${ }^{8}$ Although a hanging topic with comma intonation is possible.

${ }^{9}$ See 42 below for illustration.

${ }^{10}$ See Legate $2010 \mathrm{~b}$ for a fuller consideration of Acehnese object voice as contrasted with the LE-construction. This object voice construction is described in Asyik 1982 and 1987 as the agent serving as an agreement 'substitute' (since the agreement prefix is lost; see $\S 4.2$ ), and in Durie 1985:205-7 and Asyik 1987 as AGENT CLITICIZATION. For the Indonesian cognate, sometimes referred to as PASSIVE TYPE 2, see, for example, Chung 1976, Guilfoyle et al. 1992, Arka \& Manning 1998, Cole et al. 2008.

${ }^{11}$ It is indeed a restriction on $\mathrm{A}^{\prime}$-movement, not just topicalization. $\mathrm{A}^{\prime}$-movement over the initial DP in relative clauses and wH-questions is ungrammatical (e.g. Durie 1985) or disfavored, perhaps with some sensitivity to the presence or absence of the verbal prefix, and perhaps with dialectal variation. For example, relativization or WH-movement of an object (or of a DP from an embedded clause) is only consistently accepted as fully grammatical by my consultants if the initial DP position is not filled. Given the complexity of the issues involved, and given that they are not central to the present discussion, I leave them aside for future research.

${ }^{12}$ I do provide an analysis in Legate 2011 b, whereby only a single high specifier position is available for checking of both the subject A-features and the DP A'-features (due to failure of Chomsky's 2008 INHERITANCE operation). See that work for details. 
will show properties of an $\mathrm{A}^{\prime}$-position. For the postverbal agent, the passive analysis predicts that it will pattern as a PP adjunct, whereas the topicalization analysis predicts that it will pattern as a DP argument. I present a number of tests in $\S 4$, all of which support the passive analysis. Before that, I begin to test these predictions in $\S 3$ with a discussion of control in Acehnese. Control was a core point of disagreement between Lawler and Durie-Lawler claimed that the raised object in the LE-construction could be controlled PRO, and so must be a surface subject, ${ }^{13}$ whereas Durie claimed that Lawler's examples did not exemplify control, and that true control examples actually showed that the raised object in the LE-construction could not be controlled PRO, and thus was not a surface subject. ${ }^{14}$ My investigation concludes that the raised object can be controlled PRO in Acehnese and that Durie's examples involve restructuring verbs. Thus, the discussion provides evidence for a passive analysis of the LE-construction, and for a $v$ analysis of the verbal prefix. I turn to this now.

3. CONTROL AND RESTRUCTURING. A key argument for a passive analysis from Lawler 1977 is that Acehnese exhibits control in embedded clauses, and that this can be fed by the passive. His examples follow, the first illustrating control-the matrix subject controls the subject of the embedded active verb, and the second illustrating passive feeding control-the matrix subject controls the thematic object of the embedded LE-construction. ${ }^{15}$

(8) a. Dokto geu-usaha geu-peuréksa ureung agam nyan. ${ }^{16}$ doctor 3.POL-arrange 3.POL-examine person male DEM

'The doctor arranged to examine that man.'

b. Jih lôn-peu-ingat lé lôn geu-peuréksa lé dokto. 3.FAM 1SG-CAUS-remember by $1 \mathrm{SG} 3$.POL-examine by doctor

'He was reminded by me to be examined by the doctor.' (Durie 1988:109)

Durie (1988; see also Durie 1987), however, points out that these embedded clauses are well-formed matrix clauses; since Acehnese exhibits pro-drop, there is no need to appeal to control to explain the null embedded subjects in Lawler's data.

(9) a. Geu-peuréksa ureung agam nyan.

3.POL-examine person male DEM

'(He) examined that man.'

b. Geu-peuréksa lé dokto.

3.POL-examine by doctor

'(He) was examined by the doctor.'

(Durie 1988:109)

Furthermore, Durie continues, there are control predicates in Acehnese, but they do not embed the LE-construction. He thus concludes that the raised theme in the LE-construction is not the grammatical subject, since it may not be controlled PRO. Durie's examples are the following, involving the matrix verb $c i$ 'try'.

${ }^{13} \mathrm{He}$ referred to this as being able to undergo 'Equi deletion'.

${ }^{14}$ They assumed, as I do, that only subjects may be controlled PRO; see also Manning 1996.

${ }^{15}$ Henceforth I gloss lé as 'by', in anticipation of my analysis.

${ }^{16}$ Durie attributes this sentence to Lawler 1977:[8a], but the correct citation is ex. 10a. Durie standardizes Lawler's spelling and improves his glosses and translations; thus I cite Durie's version of the data rather than Lawler's. I have adjusted Durie's glossing slightly (e.g. glossing lé as 'by' and separating out causative morphemes), and I have corrected typos (e.g. in the following example jih is the familiar third-person pronoun, not the polite). 
(10) a. Dokto geu-ci (*geu-)peuréksa ureung agam nyan. doctor 3.POL-try 3.POL-examine person male DEM

'The doctor tried to examine that man.'

b. *Ureueng agam nyan ji-ci geu-peuréksa lé dokto. person male DEM 3.FAM-try 3.POL-examine by doctor

'The man tried to be examined by the doctor.'

(Durie 1988:109)

Durie points out that the verbal prefix is not possible in the complement of these predicates (in contrast with Lawler's examples). Assuming that the prefix represents subject agreement on finite INFL, Durie takes this as evidence of the nonfinite status of the embedded clause.

The same pattern is also found with another matrix verb meaning 'try', cuba.

(11) Aneuk miet nyan ji-cuba (*ji-)pajôh batée. child small DEM 3.FAM-try 3.FAM-eat rock

'The child tried to eat a rock.'

In order to fully develop the question of whether the LE-construction may contain a thematic object as controlled PRO, here I anticipate the analysis of the verbal prefix as $v$ to be developed in $\S 4$. Under such an analysis, the absence of the verbal prefix indicates not the presence of nonfinite INFL and control, but rather the absence of $v$ P. From this perspective, these matrix 'try' predicates are not embedding a nonfinite clause, but rather a radically truncated structure, consisting only of the lexical verb phrase. ${ }^{17}$ Such constructions analyzed in this way thus exemplify restructuring rather than control, under an analysis like that of Wurmbrand $2001 .{ }^{18}$ And indeed, predicates meaning 'try' are typical restructuring predicates crosslinguistically. The tree in 12 illustrates the syntactic structure of restructuring 'try'.

(12)

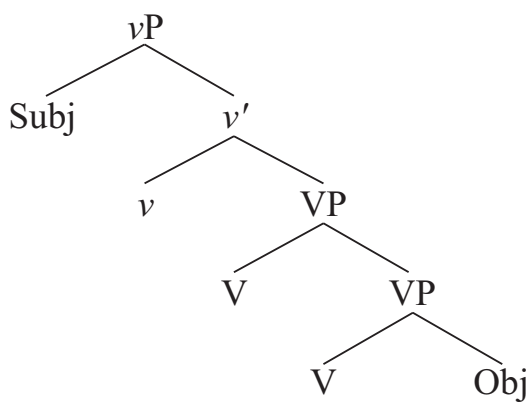

Under the restructuring analysis, the embedded truncated clause lacks both an external argument and the ability to assign accusative case (both of which are associated with the $v \mathrm{P}$ projection). The embedded object is dependent for case on the embedding verb (more precisely, the $v \mathrm{P}$ associated with it). This makes it possible for restructuring predicates to exhibit the long passive, whereby passivization of the embedding verb results in the raising of the embedded object. Example 13 illustrates for German.

(13) dass der Traktor zu reparieren versucht wurde that the tractor.NOM to repair tried was 'that they tried to repair the tractor'

\footnotetext{
${ }^{17}$ This is a slight simplification, in that the causative morpheme may appear. See $\S 5$ below for discussion.

${ }^{18}$ For discussion of restructuring, see also, for example, Rizzi 1982, Haegeman \& van Riemsdijk 1986, Kayne 1991, Roberts 1997, Cardinaletti \& Shlonsky 2004, Cinque 2004.
} 
Assuming that the LE-construction is a passive, as is argued fully in $\S 4$ below, the proposed restructuring analysis of the Acehnese data in 10 and 11 thus predicts the possibility for the long passive. This prediction is borne out. ${ }^{19}$

(14) a. Aneuk agam nyan geu-ci peuréksa lé dokto. child male DEM 3.POL-try diagnose by doctor

'The child was tried to be diagnosed by the doctor.' (i.e. 'The doctor tried to diagnose the child.')

b. Batée ji-cuba (*ji-)pajôh lé aneuk miet nyan. rock 3.FAM-try 3.FAM-eat by child small DEM

'The rock was tried to be eaten by the child.'

Such sentences under Durie's control analysis could be analyzed as long-distance topicalization. ${ }^{20}$ Indeed, Durie proposes long-distance topicalization for other predicates like dawa 'make a legal claim' (notice that the embedded verb is marked with the prefix under this predicate).

(15) Jih geu-dawa lé hakém ka ji-cu leumo nyan.

3.FAM 3.POL-claim by judge PERF 3.FAM-steal cow DEM

'He is claimed by the judge to have stolen that cow.' (Durie 1988:110) ${ }^{21}$

An additional property, however, distinguishes the analyses. It has been observed (e.g. Miyagawa 1987) that restructuring predicates do not allow PPs to intervene between the embedding and embedded predicate. This restriction may be characterized as the embedded VP not being subject to extraposition. ${ }^{22}$ Thus, on a restructuring analysis, we expect this restriction to hold true for these predicates. On a topicalization analysis, such a restriction is not expected; note the intervening PP in the long-distance topicalization example above (15) and in 16. (On the present analysis, both of these would be raising-to-subject constructions.)

(16) Kah geu-anggap lé gopnyan meunang-keuh.

2.FAM 3.POL-consider by 3.POL win-2.FAM

'You are considered by him/her to have won.'

(Durie 1987:381)

The restriction does hold true for the relevant predicates in Acehnese, as illustrated in 17 .

(17) a. *Batée ji-cuba lé aneuk miet nyan (ji-)pajôh. rock 3.FAM-try by child small DEM 3.FAM-eat

'The rock was tried to be eaten by the child.'

b. *Aneuk agam nyan geu-ci lé dokto peuréksa. child male DEM 3.POL-try by doctor diagnose

'The child was tried to be diagnosed by the doctor.'

I conclude that Durie's purported control examples are actually restructuring constructions, and thus do not speak to the status of the raised theme as a topic or gram-

\footnotetext{
${ }^{19}$ My Lho-nga consultant consistently translates the verb peuréksa as 'diagnose' rather than 'examine' (as in Durie's and Lawler's examples 8 and 9 above).

${ }^{20}$ Thank you to Heidi Harley for pointing this out.

${ }^{21}$ Durie cites this example from Lawler 1977, and retains Lawler's translation as 'He is considered by the judge to have stolen that cow'. In the immediately following text, Durie argues that the translation is inaccurate, so I have amended it accordingly.

${ }^{22}$ As noted by Heidi Harley (p.c.), the inability of VP to extrapose may be explained by the fact that it is not a phase, in the sense of Chomsky 2000 and subsequent.
} 
matical subject. ${ }^{23}$ This reopens the question of whether there exist control predicates in Acehnese. Since the language lacks tense morphology, we will not be able to use the lack of tense to identify nonfinite clauses; as discussed above and in $\S 4$ below, nor can we use the agreement prefixes - a nonfinite clause will exhibit the prefixes. We must therefore use established tests to diagnose the pro versus PRO distinction.

For this purpose, I enlist strict versus sloppy interpretation under ellipsis (see Landau 2004 for discussion of this diagnostic). Pronouns, including pro, give rise to a strictversus sloppy-identity ambiguity under ellipsis, corresponding to their status as coreferent versus bound. Control, by contrast, only allows the sloppy interpretation; coreference is impossible, since PRO cannot refer.

(18) a. Kim promised that she would behave, and the teacher did too. YES strict: The teacher promised that Kim would behave. YES sloppy: The teacher promised that the teacher would behave.

b. Kim promised to behave, and the teacher did too. NO strict: The teacher promised that Kim would behave. YES sloppy: The teacher promised that the teacher would behave.

Using this test, let us revisit the disputed control examples from the examples in 8 above. They involve the matrix predicates useuha 'arrange' 24 and peu-ingat 'remind'. I first confirm that these predicates indeed allow an embedded LE-construction.

(19) a. Fatimah geu-useuha geu-peuréksa lé dokto. Fatimah 3.POL-arrange 3.POL-diagnose by doctor 'Fatimah arranged to be diagnosed by the doctor.'

b. Fatimah lôn-peu-ingat geu-peuréksa lé dokto.

Fatimah 1sG-CAUS-remember 3.POL-diagnose by doctor 'Fatimah was reminded by me to be diagnosed by the doctor.'

The question is whether the null embedded subject should be identified as pro or PRO. A pro analysis predicts both strict and sloppy identity under ellipsis, whereas a PRO analysis predicts only sloppy. As illustrated in 20, only sloppy identity is possible under ellipsis.

${ }^{23}$ The restructuring analysis may also explain conflicting judgments as interspeaker variation in the class of restructuring predicates. Durie (1987:373) reports the following as ungrammatical, whereas all of my consultants find it grammatical. (This includes my speakers from the North Aceh dialect, which is the dialect spoken by Durie's consultants.)

(i) \%Aneuk agam nyan ji-tém geu-peuréksa lé dokto. child male DEM 3.FAM-want 3.POL-examine by doctor

'That boy wants to be examined by the doctor.'

(Durie 1987:373)

This is explained if the speakers Durie consulted use tém 'want' only as a restructuring predicate, whereas those I consulted allow a control structure. This would also explain the ungrammaticality for Durie's consultants of an unaccusative predicate under tém 'want': the embedded verb in a restructuring structure is semantically interpreted as sharing the same thematic subject as the embedding verb, and yet the unaccusative verb cannot have a thematic subject. Durie's example follows.

(ii) *Gopnyan geu-tém rhët.

'(S)he wants to fall.'

(Durie 1987:373)

Note that on Durie's analysis the restriction against embedded unaccusatives must simply be imposed by fiat; for example, Durie states that 'the controlee must be an Actor' (1987:373). On the restructuring analysis, the restriction is explained, as detailed above.

${ }^{24}$ In my Lho-nga consultant's dialect, the verb is useuha rather than usaha (as given by Durie in ex. 8 above); he suggested 'try, attempt, effort' as possible alternative translations. 
(20) a. Fatimah geu-useuha geu-peuréksa lé dokto, meunan cit Ibrahim. Fatimah 3.POL-arrange 3.POL-diagnose by doctor like.that also Ibrahim

'Fatimah arranged to be diagnosed by the doctor, and so did Ibrahim.' NO strict: Ibrahim arranged for Fatimah to be diagnosed by the doctor. YES sloppy: Ibrahim arranged for Ibrahim to be diagnosed by the doctor.

b. Fatimah lôn-peu-ingat geu-peuréksa lé dokto, meunan cit

Fatimah 1sG-CAUS-remember 3.POL-diagnose by doctor like.that also Ibrahim. Ibrahim

'Fatimah was reminded by me to be diagnosed by the doctor, and so was Ibrahim.'

NO strict: Ibrahim was reminded by me that Fatimah should be diagnosed by the doctor.

YES sloppy: Ibrahim was reminded by me that Ibrahim should be diagnosed by the doctor.

Furthermore, these contrast with embedded finite clauses with a pronominal subject, which allow both strict and sloppy identity. For example, in the following, the matrix predicate piké 'think' takes an embedded finite clause, with the modal akan 'will' and a pro subject. Both strict and sloppy identity are possible.

(21) a. Fatimah geu-piké akan geu-beurangkat singoh, Ibrahim geu-piké Fatimah 3.POL-think will 3.POL-leave tomorrow Ibrahim 3.POL-think meunan cit. like.that also

'Fatimah thinks that she will leave tomorrow, and Ibrahim thinks so too.'

YES strict: Ibrahim thinks that Fatimah will leave tomorrow.

YES sloppy: Ibrahim thinks that Ibrahim will leave tomorrow.

b. Fatimah geu-piké akan geu-beurangkat singoh, meunan cit

Fatimah 3.POL-think will 3.POL-leave tomorrow like.that also

Ibrahim.

Ibrahim

'Fatimah thinks that she will leave tomorrow, and Ibrahim does too.'

YES strict: Ibrahim thinks that Fatimah will leave tomorrow.

YES sloppy: Ibrahim thinks that Ibrahim will leave tomorrow.

The data in 19 and 20 therefore contain control clauses in which the raised theme in the LE-construction is controlled PRO. This constitutes a strong argument that the raised object is a grammatical subject, and thus that the LE-construction is a passive, rather than a theme topic.

In the following section, I provide additional supporting arguments for this conclusion, first considering the status of the raised theme, and then turning to the postverbal agent.

\section{THE LE-CONSTRUCTION AS A PASSIVE.}

4.1. The RAISED OBJeCt AS A GRAMMATICAL SUBJECT. In this subsection, I consider the status of the raised object in the LE-construction. I present two additional tests to distinguish its surface position as an A- or A'-position. In both instances, the position of the raised object patterns as an A-position, as predicted by a passive analysis of the LE-construction, rather than an $\mathrm{A}^{\prime}$-position as would be expected on a theme-topic analysis. 
The first test comes from CONDITION $\mathrm{C}$ reconstruction effects. It is well known that condition $\mathrm{C}$ reconstruction effects are found with $\mathrm{A}^{\prime}$-movement, but not with $\mathrm{A}$-movement (e.g. Lebeaux 1995, Fox 1999; see also Sportiche 2011 for an insightful analysis). In other words, A-movement repairs an underlying condition $\mathrm{C}$ violation, while $\mathrm{A}^{\prime}$-movement cannot. To begin, I note that in active SVO clauses in Acehnese, standard condition C effects apply. ${ }^{25}$

(22) SVO active

a. Mie aneuk-aneuk miet nyan ji-kap awaknyan. ${ }^{26}$ cat child-child small DEM 3.FAM-bite 3PL

'The children ${ }_{i}$ 's cat bit them ${ }_{i / k}$.'

b. Awaknyan ji-poh mie aneuk-aneuk miet nyan. 3PL 3.FAM-hit cat child-child small DEM

'They $k_{k * i}$ hit the children ${ }_{i}$ 's cat.'

Furthermore, A'-movement in Acehnese, as in English, does not repair a condition C violation. Since A'-movement of a DP over a subject is not permitted, I use a PP based on the preposition keu 'to'. Example 23a illustrates the underlying condition $\mathrm{C}$ violation with a keu-phrase, and 23b illustrates that the violation remains under uncontroversial $\mathrm{A}^{\prime}$-movement: the pronoun cannot covary with the R-expression embedded inside the WH-phrase; it must be free.

(23) a. Awaknyan ji-jôk eumpeuen keu mie aneuk-aneuk nyan. 3PL 3.FAM-give animal.food to cat child-child DEM 'They $*_{i / k}$ gave food to the children ${ }_{i}$ 's cat.'

b. Keu mie aneuk-aneuk nyan nyang toh awaknyan ji-jôk to cat child-child DEM COMP which 3PL 3.FAM-give eumpeuen? animal.food

'To which children ${ }_{i}$ 's cat did they $*_{i / k}$ give food?'

Now consider the LE-construction. If it is a theme-topic construction, the agent is a subject that c-commands the object before $\mathrm{A}^{\prime}$-movement. Therefore, if the subject is a pronoun coindexed with an R-expression inside the object, we should find condition $\mathrm{C}$ effects (under reconstruction). If, however, the construction is a passive, the agent is in a $b y$-phrase adjunct and there is no condition $\mathrm{C}$ violation at any point in the structure. Therefore, we should not find condition C effects. As illustrated in 24, a pronominal agent may be grammatically coindexed with an R-expression inside the raised objectno condition $\mathrm{C}$ effects are found.

(24) Mie aneuk-aneuk miet nyan ji-poh lé awaknyan. cat child-child small DEM 3.FAM-hit by 3PL

'The children ${ }_{i}$ 's cat was hit by them $i / k$.'

This lack of condition $\mathrm{C}$ reconstruction effects supports the passive analysis.

For the second test, consider WEAK CROSSOVER (WCO) effects. The theoretical formulation of the principle underlying these effects is controversial; for our purposes, the

\footnotetext{
${ }^{25}$ These data are neutral with respect to the two analyses, since the underlying and surface c-command relationships of the subject and object are identical.

${ }^{26}$ awaknyan is morphologically transparently composed of awak 'person' and the nonproximal demonstrative nyan. Durie (1985:118) states that in its pronominal use it is neutral with respect to person and is often, but not exclusively, plural; he does not provide examples. In my data, it is used only in third-person plural, and thus I gloss it as such, while noting that it may have a broader usage.
} 
crucial aspect of this principle is that it differentiates between A- and $\mathrm{A}^{\prime}$-positions. For example, Büring (2004:24) states the following.

(25) The A-command requirement on pronoun binding: Pronoun binding can only take place from a c-commanding A-position.

(See also Reinhart 1983 and Ruys 2000, inter alia.) In addition, since the task is to differentiate a grammatical subject position from a topic position, we must use quantificational objects attempting to bind a pronoun inside the agent. By using a quantificational object, we avoid the issue of weakest crossover, whereby a nonquantificational DP undergoing $\mathrm{A}^{\prime}$-movement (including topicalization) may fail to exhibit weak crossover effects (see Lasnik \& Stowell 1991, Postal 1993, Ruys 2004). The objects in the examples are based on the Acehnese quantifiers tieptiep 'every' and karap mandum 'almost all'. Phrases based on these quantifiers show the expected quantificational behavior in the SVO active: the agent can bind into the theme, but not vice versa, since the agent asymmetrically c-commands the theme from an A-position.

(26) SVO active

a. Tieptiep mak geu-lindong aneuk geuh. every mother 3.POL-protect child 3.POL

'Every mother ${ }_{i}$ protects her $_{i}$ child.'

b. Aneuk geuh geu-lindong tieptiep mak. child 3.POL 3.POL-protect every mother

'His/her $k_{k^{*} i}$ child protects every mother ${ }_{i}$ ',

(27) SVO active

a. Karap mandum gurée geu-peu-runoe mured geuh. almost all teacher 3.POL-CAUS-learn student 3.POL

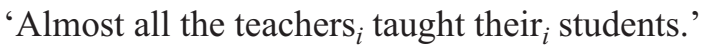

b. Gurée jih geu-peu-runoe karap mandum mured. teacher 3.FAM 3.POL-CAUS-learn almost all student

'His/her ${ }_{k{ }^{*} i}$ teacher taught almost all the students ${ }_{i}$.'

Furthermore, uncontroversial A'-movement does exhibit the expected WCO effects in Acehnese. Again, since $\mathrm{A}^{\prime}$-movement of a DP over a subject is not permitted, I use a keu-PP. A quantifier phrase embedded inside a keu-PP can bind out of the PP.

(28) Dokto nyan akan geu-jôk keu tieptiep mak aneuk geuh. doctor DEM will 3.POL-give to every mother child 3.POL

'The doctor will give to every mother $_{i}$ her $_{i / k}$ child.'

But it cannot bind into the subject.

(29) Mak jih geu-jôk meuneu'en keu tieptiep aneuk. mother 3.FAM 3.POL-give toy to every child

'His ${ }_{*_{i / k}}$ mother gives toys to every child ${ }_{i}$ '

$\mathrm{A}^{\prime}$-movement of the keu-PP does not create new binding possibilities, but instead shows WCO effects. Thus, 30 is grammatical only on the interpretation whereby the pronoun refers independently rather than covarying with the wH-phrase.

(30) Keu soe mak jih geu-jôk meuneu'en?

to who mother 3.FAM 3.POL-give toy

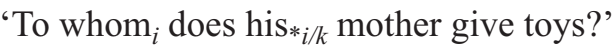

Turning to the LE-construction, I use the quantifier phrase as the raised object and attempt to bind into the agent. The raised object position patterns as a grammatical subject position (i.e. A-position), not a topicalized position (i.e. A'-position): the raised theme binds into the agent. 
(31) a. Tieptiep aneuk geu-lindong lé mak droe-jih. every child 3.POL-protect by mother self-3.FAM

'Every child ${ }_{i}$ is protected by his/her ${ }_{i}$ mother.'

b. Karap mandum mured geu-peu-runoe lé gurée droe-jih. almost all student 3.POL-CAUS-learn by teacher self-3.FAM

'Almost all the students ${ }_{i}$ were being taught by their ${ }_{i}$ own teacher.'

In summary, the raised object in the LE-construction behaves as a grammatical subject occupying an A-position rather than a topic occupying an $\mathrm{A}^{\prime}$-position. The raised object may be controlled PRO; the raising does not exhibit condition $\mathrm{C}$ reconstruction effects, and creates new binding configurations rather than triggering weak crossover effects.

4.2. The lé-MARKED AGENT AS A PP ADJUNCT. In this subsection, I turn to the status of the lé-marked agent. Durie's analysis treats the agent as the thematic subject, overtly marked with ergative case morphology when not topicalized. In contrast, a passive analysis treats the agent as an adjunct inside a prepositional phrase akin to the English by-phrase. Several tests support the passive approach.

First, consider the generalization mentioned in $§ 2$ that topicalization of a DP before the initial DP position is ungrammatical; examples were provided in 5 above. As Durie demonstrates (e.g. 1987:380), this restriction does not extend to prepositional phrases. Prepositional phrases may topicalize to a position before the initial DP position.

(32) a. Keu ureueng inong nyan boh mamplam ka lôn-jôk.

to person female DEM fruit mango PERF 1SG-give 'To that woman the mango I gave.'

b. Dari blang lôn ka lôn-gisa.

from rice.field 1SG PERF 1SG-return

'From the rice field I returned.'

c. Di sinoe aneuk miet meukèn-meukèn.

at here child small play-play

'Children play here.'

Durie did not test whether the lé-marked agent may topicalize. His analysis predicts that it should not for two reasons. First, the agent is a DP, not a PP, and as shown in 5 above, a DP may not topicalize before the initial DP position. Second, to explain the absence of lé in the SVO active construction, Durie claims that topicalization of the agent results in elimination of the ergative case marker lé; therefore, the agent should not topicalize while retaining lé. Durie's prediction is not borne out, however; the lé-phrase may topicalize.

(33) a. Lé uleue nyan aneuk miet nyan di-kap. by snake DEM child small that 3.FAM-bite

'By the snake, that child was bitten.'

b. Lé dokto Ibrahim ka geu-peu-ubat. by doctor Ibrahim PERF 3.POL-CAUS-medicine

'By the doctor, Ibrahim was treated.'

The lé-phrase thus patterns for this test as a prepositional phrase, rather than a DP, as expected on the passive analysis.

Next, I discuss another test that distinguishes noun phrases from prepositional phrases, based on questions with the complementizer (n)yang. ${ }^{27} \mathrm{WH}$-questions involving nomi-

27 There is variability in the pronunciation of this complementizer. 
nal wH-phrases show two extraction strategies, one with the complementizer and one without.

(34) Soe (yang) geu-peu-ubat lé dokto?

who COMP 3.POL-CAUS-medicine by doctor

'Who was treated by the doctor?'

The distinction between these two strategies is not yet well understood, although this complementizer is otherwise found in relative clauses, and similar phenomena in other Austronesian languages have been argued to involve clefts or pseudoclefts (e.g. Paul 2001, Aldridge 2002, Massam 2003, Potsdam 2006, 2009). What is most relevant for current purposes is that WH-questions involving prepositional phrases and adjuncts may not be questioned using the complementizer strategy. This is illustrated in 35 for the wH-phrases pajan 'when', pat 'where', and keu soe 'to whom'.

(35) a. Pajan (*yang) Fatimah geu-kalon Ibrahim?

when COMP Fatimah 3.POL-see Ibrahim

'When did Fatimah see Ibrahim?'

b. Pat (*yang) Fatimah geu-kalon Ibrahim? where COMP Fatimah 3.POL-see Ibrahim

'Where did Fatimah see Ibrahim?'

c. Keu soe (*yang) geu-jôk lé ureueng agam nyan aneuk miet nyan? to who COMP 3.POL-give by person male DEM child small DEM 'To whom was the child given by the man?'

Thus we have another test that distinguishes DPs from adjuncts and PPs. Considering the behavior of lé-marked WH-agents, we discover that they pattern with prepositional phrases and adjuncts: the lé-phrase cannot be questioned with (n)yang. ${ }^{28}$

(36) a. Lé soe (*yang) aneuk miet nyan geu-jôk keu ureueng inong nyan? by who COMP child small DEM 3.POL-give to person female DEM

'By whom was the baby given to the woman?'

b. Lé soe (*nyang) Ibrahim geu-peu-ubat? by who COMP Ibrahim 3.POL-CAUS-medicine

'By whom was Ibrahim treated?'

Floating quantifiers, like dum 'much' and mandum 'all', also distinguish between DPs and PPs. Internally to a DP, quantifiers may appear initially, postnominally, or finally.

(37) a. mandum ureueng agam nyan all person male DEM

'all the men'

b. ureueng agam mandum nyan person male all DEM 'all the men'

c. mandum asèe nyoe all $\operatorname{dog}$ this 'all these dogs'

d. asèe nyoe mandum dog this all 'all these dogs'

\footnotetext{
${ }^{28}$ That it may be questioned at all in the presence of a distinct surface subject would be surprising if it were a DP; see n. 11 .
} 
Floated quantifiers appear in several positions in the clause, including immediately preverbally, immediately postverbally, and among/after other postverbal elements. It is important to note that quantifiers may float not only from the initial DP, but also from other DPs in the clause. The following illustrate several possible floated positions, 38a for the subject and $38 \mathrm{~b}$ for the object.

(38) a. Ureueng agam nyan (mandum) geu-keumeukoh ${ }^{29}$ (mandum) di blang. person male DEM all 3.POL-harvest all in rice.field

'All the men are going to harvest rice in the field.'

b. Ureueng nyan ka (dum) geu-pajôh (dum) boh drien (dum) uroe nyoe. person DEM PERF much 3.POL-eat much fruit durian much day this

'That person ate a lot of durian today.'

Floating is not possible, however, from prepositional phrases. For example, 38a with the quantifier in either position cannot mean 'The men are going to harvest rice in all the fields'. For the quantifier to modify a DP within a PP, the quantifier must be internal to the DP. In 39a, the quantifier is unambiguously internal to the DP 'the rice fields' within the PP 'in the rice fields', and that is the only possible interpretation. In 39b, the string is structurally ambiguous; the quantifier could be final within the DP 'the rice fields', or it could be floated; accordingly 'all' can be associated either with 'the rice fields' or with the object 'rice'. Example 39c disambiguates 39b in favor of the floated structure by placing a clausal adverb between the demonstrative and the quantifier; revealingly, the quantifier may no longer be associated with the DP embedded within a PP, but may still be associated with the object.

(39) a. Ureueng agam nyan geu-koh padé lam mandum blang nyan person male DEM 3.POL-cut raw.rice in all rice.field DEM baroe. yesterday

'That man cut rice in all the rice fields yesterday.'

b. Ureueng agam nyan geu-koh padé lam blang nyan mandum person male DEM 3.POL-cut raw.rice in rice.field DEM all baroe. yesterday

'That man cut all the rice in the rice fields yesterday.'

OR 'That man cut rice in all the rice fields yesterday.'

c. Ureueng agam nyan geu-koh padé lam blang nyan baroe person male DEM 3.POL-cut raw.rice in rice.field DEM yesterday mandum. all

'That man cut all the rice in the rice fields yesterday.' NOT 'That man cut rice in all the rice fields yesterday.'

If the lé-phrase is a prepositional phrase, we therefore expect it not to allow quantifier float from the agent. If the lé-phrase is a DP, we expect it to allow quantifier float, like the subjects and objects in 38. In fact, the agent in a lé-phrase does not allow quantifier float, as illustrated in 40, which provides the identical paradigm to 39 .

(40) a. Boh drien geu-pajôh lé mandum ureueng nyan baroe. fruit durian 3.POL-eat by all person DEM yesterday

'Durian was eaten by all the people yesterday.'

\footnotetext{
${ }^{29}$ The root of this word is $k o h$ 'cut; harvest rice'; the function of the prefixes keu- and meu- are unclear; see Cowan 1981 for discussion.
} 
b. Boh drien geu-pajôh lé ureueng nyan mandum baroe. fruit durian 3.POL-eat by person DEM all yesterday

'All the durian was eaten by that person yesterday.'

OR 'Durian was eaten by all the people yesterday.'

c. Boh drien geu-pajôh lé ureueng nyan baroe mandum. fruit durian 3.POL-eat by person DEM yesterday all

'All the durian was eaten by that person yesterday.'

NOT 'The durian was eaten by all the people yesterday.'

The lé-marked agent also exhibits the distribution of a prepositional phrase. In this respect, it is instructive to compare the LE-construction to the OBJECT VOICE construction, introduced in $\S 2$ (see 6 above), since the object voice construction reveals the behavior of an agent that fails to raise to the initial position. In the object voice construction, the agent appears obligatorily preadjacent to the verb (in its $\theta$-position in the specifier of $v \mathrm{P})$. In the LE-construction, in contrast, the agent appears postverbally, freely ordered with other prepositional phrases.

(41) LE-construction

a. Sie ji-taguen lé Fatimah keu lôn bak dapu. meat 3.FAM-cook by Fatimah to $1 \mathrm{sg}$ at kitchen

'The meat was cooked by Fatimah for me in the kitchen.'

b. Sie ji-taguen keu lôn lé Fatimah bak dapu. meat 3.FAM-cook to $1 \mathrm{SG}$ by Fatimah at kitchen

'The meat was cooked for me by Fatimah in the kitchen.'

c. Sie ji-taguen bak dapu keu lôn lé Fatimah. meat 3.FAM-cook at kitchen to $1 \mathrm{SG}$ by Fatimah

'The meat was cooked in the kitchen for me by Fatimah.'

(42) Object voice

a. Sie akan Fatimah taguen keu lôn bak dapu. meat will Fatimah cook to 1SG at kitchen

'Meat will be cooked by Fatimah for me in the kitchen.'

b. *Sie Fatimah akan taguen keu lôn bak dapu. meat Fatimah will cook to $1 \mathrm{SG}$ at kitchen 'Meat will be cooked by Fatimah for me in the kitchen.'

c. Sie hana Fatimah taguen keu lôn bak dapu. meat NEG Fatimah cook to $1 \mathrm{SG}$ at kitchen

'Meat was not cooked by Fatimah for me in the kitchen.'

d. *Sie Fatimah hana taguen keu lôn bak dapu. meat Fatimah NEG cook to $1 \mathrm{SG}$ at kitchen

'Meat was not cooked by Fatimah for me in the kitchen.'

e. Sie teungoh Fatimah taguen keu lôn bak dapu. meat PROG Fatimah cook to 1SG at kitchen

'Meat is being cooked by Fatimah for me in the kitchen.'

f. *Sie Fatimah teungoh taguen keu lôn bak dapu. meat Fatimah PROG cook to 1SG at kitchen

'Meat is being cooked by Fatimah for me in the kitchen.'

Furthermore, in the object voice, the agent is obligatory, as the thematic subject. ${ }^{30}$ In the LE-construction, in contrast, the agent is optional, ${ }^{31}$ as expected of a PP adjunct.

\footnotetext{
${ }^{30}$ Pro-drop does not seem possible for the agent in the object voice.

${ }^{31}$ Lawler (1977:224, n. 11) remarks that the lé-phrase is not omissible, unlike the English by-phrase. Durie states: '[t]his claim is false, and it is hard to understand L[awler]'s basis for making it. Sentences with the lé-
} 
(43) a. LE-construction

Aneuk nyan di-kap (lé uleue nyan).

child DEM 3.FAM-bite by snake that

'The child was bitten (by the snake).'

b. Object voice

Aneuk nyan *(uleue nyan) kap.

child DEM snake that bite

'The child was bitten (by the snake).'

Finally, when the agent is not phonetically present, the interpretation is as expected of a passive rather than an active. If the LE-construction were an active clause with omission of the agent due to pro-drop, we would expect a pronominal interpretation. If, by contrast, the LE-construction is a passive, with omission of the agent due to the optionality of PP adjuncts, we expect an existential interpretation. ${ }^{32}$ The following illustrate that the interpretation is existential rather than pronominal.

(44) a. Aneuk miet nyan ka i-kap, tapi lôn hana lôn-tupeue lé peue. child small DEM PERF 3.FAM-bite but 1 SG NEG 1 SG-know by what

'The child was bitten, but I don't know by what.'

b. Kalon uleue nyan! Aneuk miet nyan i-kap \#(lé jih). look snake DEM child small that 3.FAM-bite by 3.FAM

'Look at that snake! The child was bitten by it.'

We have now seen a number of tests, which all lead to the same conclusions: the raised object occupies the grammatical subject position, and the lé-marked agent is a PP adjunct. Given the weight of evidence, I conclude that the LE-construction in Acehnese is a passive. Durie's competing theme-topic analysis must be abandoned.

Recall, however, that this conclusion reopens the puzzle of the verbal prefix. How is it that a verbal prefix in Acehnese registers the person and politeness features of the agent of a passive? I turn to this question now.

5. THE VERBAL PREFIX AS $v$. Given the conclusion of the previous sections that the LEconstruction in Acehnese is a passive, the fact that the verb registers agreement with the agent is remarkable. I repeat here the illustrative examples from 3 above.

(45) a. Aneuk miet nyan meu-tingkue lé kamoe. child small DEM 1.EXCL-carry by 1.EXCL

'The child is carried by us.'

b. Aneuk miet nyan neu-tingkue lé droeneuh. child small DEM 2.POL-carry by 2.POL

'The child is carried by you.'

c. Aneuk miet nyan geu-tingkue lé gopnyan. child small DEM 3.POL-carry by 3.POL

'The child is carried by him/her.'

I argue that the Acehnese verbal prefix is not a clausal agreement marker (e.g. associated with finite INFL, as assumed in Durie 1988), but rather the morphological real-

phrase "deleted" are not only perfectly acceptable, but are much more numerous in actual discourse than sentences with an overt lé-phrase' (1988:108, n. 8). My consultants confirm that the lé-phrase can certainly be dropped. However, Lawler's initial claim is understandable (indeed, several students in the field methods class I co-taught with Abby Cohn initially made the same claim): given the lack of a passive morpheme, the passive without a lé-phrase can be misinterpreted as an active out of context, and thus rejected by the consultant as ungrammatical (due to agreement/thematic/meaning mismatches).

32 This interpretation arises through existential closure of the argument position for the thematic subject. 
ization of the functional head that introduces the external argument. We have already seen evidence in $\S 3$ above that when the clause is truncated to the VP, the prefix is omitted, whereas the prefix appears in nonfinite (control) clauses. Thus, we know that the prefix is associated with a projection above VP, but is not associated with finiteness. We can, however, place the morpheme more precisely.

First, consider its positioning with respect to functional heads outside the verb phrase. It appears low in the clausal structure, below modals, negation, and aspect (all of which are free morphemes).

(46) a. Gopnyan jeuet geu-pajôh boh mamplam nyan.

3.POL may 3.POL-eat fruit mango DEM

'He may eat the mango.'

b. Gopnyan hana geu-poh asèe nyan baroe.

3.POL NEG 3.POL-hit dog DEM yesterday

'He didn't hit the dog yesterday.'

c. Gopnyan teungoh geu-plueng jinoe.

3.POL PROG 3.POL-run nOW

'He is running now.'

d. Gopnyan ka geu-kalon buya nyan.

3.POL PERF 3.POL-see crocodile DEM

'He has seen the crocodile.'

If this were clausal agreement morphology, in contrast, we would normally expect it to be associated with a high functional projection in the clause (e.g. INFL). Indeed, attempts to place the morpheme on higher modal or aspectual markers results in ungrammaticality.

(47) a. Droeneuh (*neu-)pasti ka*(neu-)pajôh sie.

2.POL 2.POL-must PERF 2.POL-eat meat

'You must have eaten meat.'

b. Ureueng inong nyan (*geu-)teungoh*(geu-)taguen bu.

person female DEM 3.POL-PROG 3.POL-cook cooked.rice

'The woman is cooking rice.'

So, the higher bound of its possible syntactic positions is below aspect. We can identify the lower bound by considering verb-phrase-internal morphemes. When there is a causative morpheme, the prefix appears outside the causative morpheme, not on the lexical root, as in 48 (on Acehnese causatives, see Cowan 1981:536-38, Durie 1985: 78-86, Asyik 1987:84-92, Ko 2008).

(48) a. Hasan geu-peu-reubah aneuk nyan.

Hasan 3.POL-CAUS-fall child DEM

'Hasan caused the child to fall.'

b. Hasan geu-peu-raya rumoh gopnyan.

Hasan 3.POL-CAUS-big house 3.POL

'Hasan enlarges his house.'

Although causative morphemes have been analyzed as instances of $v$ (e.g. Svenonius 2001, Folli \& Harley 2004, Travis 2005, Harley 2008), other work has argued for a distinction between a head that introduces causation but no argument, and a head that introduces the external argument (e.g. Pylkkänen 1999, 2008, Marantz 2001, Alexiadou et al. 2006, Schäfer 2008, Serratos 2008, Tubino Blanco 2010, Harley 2013). In Acehnese, both heads can be overtly morphologically realized, with the causative head inside the head that introduces the external argument, as expected on semantic grounds. 
In this vein, it is instructive to return to restructuring. I argued in $\S 3$ that restructuring predicates like $c u b a$ 'try' and $c i$ 'try' embed a truncated structure lacking the projection that introduces the external argument. The prefix registering the features of the agent is accordingly eliminated. The causative head, however, remains, indicating that it is independent of, and lower than, the head introducing the external argument.

(49) Peurahô nyan geu-cuba peu-ngop lé ureueng agam nyan.

boat DEM 3.POL-try CAUS-sink by person male DEM

'The boat was tried to be sunk by that man.' (i.e. 'The man tried to sink the boat.')

Researchers that separate the head introducing the external argument from the head introducing causation often refer to the former as the head of VOICEP and the latter as the head of $v \mathrm{P} .{ }^{33} \mathrm{I}$ do not follow this convention here for the sole reason that $v \mathrm{P}$ as the head that introduces the external argument is more familiar, and the VoiceP versus $v \mathrm{P}$ distinction is not central to this article (but see Legate 2011a). The crucial observation here is that the prefix appears between aspect and cause, in the structural position of the projection that introduces the external argument.

(50)

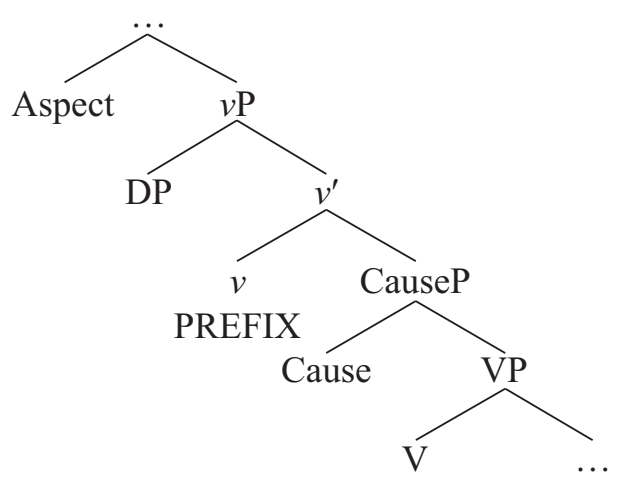

Furthermore, unlike clausal agreement, the prefix shows a close relationship with the external argument introduced by $v$. It invariably registers features of the external argument, not the surface subject. In the absence of an external argument, that is, with unaccusative (53) or nonverbal predicates (54), the prefix is simply absent (thus the split-S property discussed in Asyik 1982, Durie 1985, and subsequent).

(51) Transitive

a. Lôn ka lôn-jôk boh mamplam keu ureung inong nyan.

1SG PERF 1SG-give fruit mango to person female DEM

'I already gave the mango to the woman.'

b. Droeneuh ka neu-jôk boh mamplam keu ureung inong nyan.

2.POL PERF 2.POL-give fruit mango to person female DEM

'You already gave the mango to the woman.'

c. Ibrahim geu-jôk boh mamplam keu Fatimah.

Ibrahim 3.POL-give fruit mango to Fatimah

'Ibrahim gave the mango to Fatimah.'

(52) Unergative

a. Lôn lôn-duek ateueh kursi.

1SG 1SG-sit above chair

'I sat on the chair.'

\footnotetext{
${ }^{33}$ The label VoiceP originates with Kratzer (1996), who proposes that the head introducing the external argument is distinct from the lexical verb. The label $v \mathrm{P}$ originates with Chomsky 1995.
} 
b. Ureueng agam nyan geu-plueng.

person male DEM 3.POL-run

'The man is running.'

c. Aneuk miet nyan di-meulangue.

child small DEM 3.FAM-swim

'The child swam.'

(53) Unaccusative

a. Lôn ka (*lôn-)reubah.

1SG PERF 1SG-fall

'I fell.'

b. Dokto ka (*geu-)trôh.

doctor PERF 3.POL-arrive

'The doctor arrived.'

c. Ureueng $\left({ }^{*}\right.$ geu-)meuninggai.

person 3.POL-leave

'The person died.'

(54) Nonverbal

a. Rumoh Hasan raya.

house Hasan big.

'Hasan's house is big.'

b. Hasan teungoh seunang that.

Hasan PROG happy very

'Hasan is very happy.'

With psychological verbs, the prefix appears to be optional.

(55) a. Ibrahim geu-galak keu Fatimah.

Ibrahim 3.POL-like to Fatimah

'Ibrahim likes Fatimah.'

b. Ibrahim galak keu Fatimah.

Ibrahim like to Fatimah

'Ibrahim likes Fatimah.'

Asyik (1982) argues, however, that the alternation is indicative of an agentive/ experiencer alternation: the prefix occurs when the subject is an agent, and is absent when it is an experiencer. In the following quote, he refers to the prefix as 'pfx AM' (for prefixal agreement marker). (He also refers to a 'sfx AM', an optional verbal suffix typically related to the thematic object; this suffix has not arisen naturally in my data.)

As a native speaker I have the feeling that when the verb galak 'to like', for instance, is used with the sfx

AM the subject is the experiencer, but when it is used with the pfx AM the subject is the doer-in the

sense that he makes a conscious effort to have the feeling denoted by the verb. (Asyik 1982:16)

He provides the following example, naturally uttered in a situation in which the speaker is accused of hating a cat.

(56) Hana lôn-banci keu mie nyan.

NEG 1sG-hate at cat DEM

'I don't (make an effort to) hate the cat.'

(Asyik 1982:16)

Durie (1985:56-57) makes a similar observation, that verbs like galak 'to like' are 'also used in an intentional sense, with an Agent liker', providing the following example, of which he comments "the liker gata "you" is thought of as being able to choose to like the girl'. 
(57) Gata bek ta-galak keu dara nyan.

2 NEG.HORT 2-like to girl DEM

'Don't you take a fancy to that girl.'

(Durie 1985:57)

If we assume (as argued in e.g. McGinnis 2001, Cuervo 2003, Adger \& Ramchand 2007 ) that true experiencer subjects are generated in an applicative phrase rather than in $v \mathrm{P}$, these data again indicate that the prefix appears only in the presence of the head that assigns the external thematic role.

Finally, the prefix patterns like voice morphemes in related languages in its obligatory absence in the object voice (e.g. for Indonesian/Malay dialects see Chung 1976, Sneddon 1996, Aldridge 2008, Cole et al. 2008, Sato 2012). ${ }^{34}$ Example 58 illustrates for Acehnese object voice.

(58) a. Aneuk miet nyan uleue nyan (*di-)kap. child small DEM snake that 3.FAM-bite

'The snake bit the child.'

b. Aneuk miet nyan akan ureueng inong nyan (*geu-)tingkue. child small DEM will person female that 3.POL-carry.in.cloth

'The woman will carry the child.'

This identical patterning is notable in that the relevant morphemes in related languages do not exhibit agreement. For example, Indonesian exhibits the active prefix $m e N$ - and the passive prefix $d i$-. The single set of Acehnese agreement prefixes subsumes both of these environments. The following illustrates for Indonesian the prefixes on the active and passive and the absence of the prefix on the object voice.

(59) Indonesian

a. Active

Kami tidak akan mem-baca buku ini.

1PL not will ACT-read book this

'We will not read this book.'

b. Passive

Buku ini tidak akan di-baca (oleh) Siti. book this not will PASS-read by Siti

'This book will not be read by Siti.'

c. Object voice

Buku ini tidak akan kami baca.

book this not will 1PL read

'This book will not be read by us.'

(Cole et al. 2008:1512)

Moreover, in some varieties of related languages (see e.g. Chung 1978 on informal Indonesian, Cole \& Hermon 1998 on Singaporean Malay, and Cole et al. 2008 on Mudung Darat Malay), the active prefix is optional, while the passive prefix is obligatory. My consultants from Lho-nga and Aceh Utara also show this additional sensitivity to voice; thus, despite the fact that the same set of prefixes is used in the active and passive, the prefix is optional in the active, but obligatory in the passive. The following data are from my Lho-nga consultant.

\footnotetext{
${ }^{34}$ I leave aside the explanation of this pattern. One possibility is Sportiche's (1992) DOUBLY FILLED VOICE FILTER, adapted by Travis (2000) for Tagalog, Pearson (2001) for Malagasy, and Legate (2011c) for Acehnese. Such an analysis of the object voice requires that the prefix is $v$ : it claims that the head and specifier of $v \mathrm{P}$ cannot both be pronounced, thus identifying the prefix as the head of $v \mathrm{P}$.
} 
(60) a. Jih (i-)peu-luka droen.

3.FAM 3.FAM-CAUS-Wound 2.POL

'He hurt you.'

b. Droen*(i-)peu-luka lé jih.

2.POL 3.FAM-CAUS-wound by 3.FAM

'You were hurt by him.'

c. Lôn jeuet (lôn-)peu-jaga droen.

1SG able 1SG-CAUS-awake 2.POL

'I can wake you up.'

d. Droen jeuet *(lôn-)peu-jaga lé lôn.

2.POL can 1SG-CAUS-awake by $1 \mathrm{SG}$

'You can be woken up by me.'

I conclude that the Acehnese prefix is located in $v$. Let us now consider possible analyses. To begin, consider whether the prefix should be analyzed as agreement with the agent. AGREEMENT is a term that is used in many different ways, for phenomena that are syntactically and/or morphologically distinct (see Corbett 2006 for a recent survey). It is clear that in a broad sense the prefix may be termed agreement: it is a dependent morpheme that registers the features of an argument. I am interested here in a more theoretically precise question: is the prefix agreement in a syntactic sense, that is, the morphological reflex of a syntactic relationship between a functional head and an argument? I assume that this syntactic relationship is established through closest c-command (see Chomsky's (2000 and subsequent) AGREE operation). I argue that the prefix is not agreement in this sense.

There are two main difficulties with analyzing the prefix as agreement. First, in a handful of situations the preverbal morpheme does not consist of material that is plausibly analyzed as agreement. One type of example involves the use of a full pronoun in place of the prefix. Only a subset of pronouns allows for this possibility (lontuwan 'I', kamoe 'we (exclusive)', gata 'you' (Asyik 1987:274)).

(61) Kamoe kamoe=prèh bak meulasah.

1.EXCL 1.EXCL=wait at village.center

'We are waiting at the village center.'

(Asyik 1987:274)

Crucially, the pronoun in such examples occupies the prefixal position, as can be illustrated by its placement after verb-phrase-external functional projections, like that headed by modals.

(62) a. Kamoe meusti kamoe $=$ jak jinoe.

1.EXCL must 1.EXCL $=$ go now

'We must leave now.'

b. *Kamoe kamoe $=$ meusti jak jinoe.

1.EXCL 1.EXCl=must go now

'We must leave now.'

(Asyik 1987:275)

A more striking type of example involves a kinship term or title replacing the prefix (e.g. ayah 'father', guru 'teacher'), resulting in a second-person interpretation. In this case, the kinship term or title alternates with a second-person prefix. One of my consultants commented that such examples are more polite than use of the second-person polite pronoun and prefix droeneuh ... neu-. The examples in 63 illustrate the use of a kinship term/title with a second-person prefix, and those in 64 illustrate a kinship term/title substituting for the second-person prefix. 
(63) a. Macut han jeuet neu-woe meunyo goh lom bu. aunt NEG can 2.POL-go.home if not.yet cooked.rice

'You aunt cannot go home if you have not eaten rice with us yet.'

b. Teungku neu-piyôhu dalam.

religious.scholar 2.POL-rest to inside

'You teungku, please rest inside here.'

(64) a. Macut h'an jeuet macut=woe meunyo golom bu. aunt NEG can aunt $=$ go.home if not.yet cooked.rice

'You aunt cannot go home if you have not eaten rice with us yet.'

(Asyik 1987:275)

b. Teungku teungku=piyôh u dalam.

religious.scholar religious.scholar=rest to inside

'You 'teungku", please rest inside here.'

(Asyik 1987:274)

Again, the kinship term or title appears in place of the prefix, below verb-phraseexternal functional projections; see 64a and the following.

(65) *Macut macut=h'an jeuet woe meunyo golom bu. aunt aunt $=\mathrm{NEG}$ can go.home if not.yet cooked.rice

'You aunt cannot go home if you have not eaten rice with us yet.'

(Asyik 1987:275)

Asyik (1987:275) states that the pronouns, kinship terms, and titles are cliticized to the verb: they are inseparable from the verb, and do not receive independent stress.

This phenomenon differentiates the prefix from agreement. The substitution of a kinship term or title for a pronoun in formal discourse contexts is well attested crosslinguistically, and is prevalent in the languages of the region. In English we find Your Honour, My Lady, Holy Father, and so on (66).

(66) a. 'what your majesty is pleased to attribute to me as profound perspicacity is simply owing to chance' (Alexandre Dumas, The Count of Monte-Cristo)

b. 'If Your Honor can hang a boy at eighteen, some other judge can hang him at seventeen, or sixteen, or fourteen.' (Clarence Darrow's closing

argument in the trial of Nathan Leopold and Richard Loeb, 1924)

This type of usage, found only in very formal situations in English, is much more prevalent in many other languages; for example, Wallace (1983:577) describes Jakarta Malay:

Paired with /kit\&/ and /saya/ 'I' to indicate the addressee in most circumstances are not personal pronouns but kinship terms, titles, and personal names. For example, a young person just meeting another named /udın/ might use / kite/ for himself and /udın/ instead of a pronoun to refer to his interlocutor; or /bay romli/ 'older brother Romli' instead of a pronoun for 'you' with a somewhat older male addressee. If the addressee is of considerably higher status, the speaker uses /saya/ 'I', and a kinship term (e.g. /ibu?/ 'mother') or title (e.g. /tuan/ 'mister') in place of a pronoun for 'you'.

An example from Malay follows.

(67) Grandson to grandfather

Atuk kidal-la. Ni kalau main gitar 'rock' cepat popla ni grandpa left.handed-EMPH this if play guitar rock fast popular this tuk ... grandpa

'Grandpa (= you) is left-handed, grandpa. (You) would become popular very quickly if (you) played rock guitar.'

(Koh 1990:133)

Goddard (2005:19-20) describes a similar situation for Thai (where names are used to avoid pronouns), as do Kenesei and colleagues (1998:267) for Hungarian (where names 
and titles are used to avoid pronouns); also note the use for formal second person of $o$ senhor/a senhora in Portuguese, and of hadritak 'your grace' in Egyptian Arabic. Examples multiply. These pronoun replacements may trigger the agreement expected of them in other contexts, or may appear with the agreement expected of the pronoun they replace; Corbett provides the following example from Tamil.

(68) a. Mohan peecur-een.

Mohan speak.PRES-1SG

'Mohan speaking.' (lit. 'Mohan am speaking')

b. Ammaa edo paNNaa por-een.

mother something do go.PRES-1SG

'Mother is going to do something.' (lit. 'am')

(Corbett 2006:161)

In stark contrast, the substitution of a kinship term or title for an agreement affix is entirely unexpected on crosslinguistic grounds. Indeed, to the best of my knowledge, such a situation is unattested (in addition to language descriptions, see inter alia Corbett 1991, 2000, 2006, Siewierska 2004, Harbour et al. 2008, Song 2011). ${ }^{35}$ The Acehnese prefix is not patterning as agreement in this respect. The second main difficulty with an agreement analysis lies in the trigger. Syntactic agreement must be between a head and an XP, but an appropriate XP is not available in the Acehnese constructions. This is the case in both the active and passive, although perhaps more acutely so in the passive. In the active, the agent is in the wrong structural position to be able to trigger agreement, in the specifier of $v$ rather than in its complement. Although specifier-head agreement is commonly assumed, it standardly crucially involves movement of an XP from below the agreeing head to the specifier of this head (hence Chomsky's (2000) reanalysis in terms of in-situ Agree plus subsequent movement to the specifier position). This instance would be crucially different in involving agreement between a head and a DP base-generated in its specifier; no movement is involved. ${ }^{36}$ Therefore we would need to invoke a new type of specifier-head agreement - call it INHERENT agreement (on analogy with inherent case). Although I acknowledge an inherent-agreement analysis is possible for the active case, it is not for the passive.

Consider what could be triggering the agreement in the passive. The agent in the léphrase is too deeply embedded (inside a PP) and is in the wrong structural position (adjoined to $v \mathrm{P}$ ) to be able to agree with $v$. Furthermore, in the passive, the lé-phrase is optional (as discussed in $\S 4$ above), but the prefix is obligatory. ${ }^{37}$

(69) Aneuk miet nyan *(di-)kap (lé uleue nyan).

child small DEM 3.FAM-bite by snake DEM

'The child was bitten (by the snake).'

\footnotetext{
${ }^{35}$ It is perhaps also worth mentioning that the World Atlas of Language Structures online (http://wals.info/) includes a category of 'pronouns avoided for politeness' (listing Burmese, Indonesian, Japanese, Khmer, Korean, Thai, and Vietnamese), but does not include any such category in any of the sections relevant to agreement.

${ }^{36}$ Note also that it would not fall under the type of agreement between a head and its base-generated specifier that is proposed in Béjar \& Rezac 2009. (As may be expected - the Acehnese case shows none of the person hierarchy effects that are the core issue of Béjar and Rezac's article.) In their examples, it is crucial that the head first attempts to agree with an element in its complement (Chomsky's Agree operation); only if this attempt fails to produce (full) agreement do they propose that the head then agrees with its specifier. In the Acehnese case, agreement between $v$ and an element in its complement would not fail (for transitive verbs) the object would agree with $v$. The fact that the Acehnese $v$ shows agent agreement rather than object agreement indicates that the Agree operation does not apply-Acehnese $v$ does not attempt to agree with an element in its complement.

${ }^{37}$ Positing a null lé-phrase that is obligatory in the absence of an overt one would run afoul of the existential interpretation of the passive without a lé-phrase; see $\S 4$ above.
} 
Therefore, the prefix in the passive cannot be agreement triggered by the agent in the léphrase. In line with the inherent-agreement possibility for the active, could it be agreement triggered by an implicit agent in the specifier of $v \mathrm{P}$ ? If so, this agent would need to appear even in the presence of a $b y$-phrase; otherwise we would expect the agreement only in the absence of a $b y$-phrase, contrary to fact. The empirical arguments against this approach are identical to those against a pronominal analysis of the prefix, so I present them together. ${ }^{38}$

We have already seen one argument against a pronominal analysis of the prefixes in $\S 4$, where I showed that in a passive with the prefix but no lé-phrase, the interpretation was existential not pronominal (44 above, repeated here as 70).

(70) a. Aneuk miet nyan ka i-kap, tapi lôn hana lôn-tupeue lé peue. child small DEM PERF 3.FAM-bite but 1SG NEG 1sG-know by what

'The child was bitten, but I don't know by what.'

b. Kalon uleue nyan! Aneuk miet nyan i-kap \#(lé jih). look snake DEM child small that 3.FAM-bite by 3.FAM

'Look at that snake! The child was bitten by it.'

An additional argument comes from binding properties. If the prefix is pronominal, we expect it to behave as a pronoun for binding. The following example, which exploits the possibility for the grammatical subject position to be left empty, ${ }^{39}$ illustrates that the prefix does not trigger a condition $\mathrm{C}$ violation when coindexed with an $\mathrm{R}$-expression embedded inside the object. ${ }^{40}$

(71) Akan i-jaga mie aneuk-aneuk miet nyan lé awaknyan $_{k}(\mathrm{keu}$

will 3.FAM-care.for cat child-child small DEM by 3PL to droe).

self

'The children ${ }_{k}$ 's cat will be taken care of by them ${ }_{k}$.'

I conclude that neither an agreement nor a pronominal analysis of the prefix is appropriate. Let us develop an alternative. We need an analysis that allows the features of the prefix to be interpretable, but not pronominal. The location of the prefix in $v$, where the external argument $\theta$-role is introduced but not yet saturated, provides for just such an analysis. I propose that the features MODIFY the external argument position, but do not saturate it. Thus, for example, the $v$ morphologically realized as geu-introduces an

\footnotetext{
${ }^{38}$ Collins (2005) proposes an analysis of the passive whereby the thematic subject position is always filled, but an implicit agent is analyzed as $\mathrm{PRO}_{A R B}$; thus he avoids the prediction of a pronominal interpretation of the implicit agent. Such an avenue is not available for Acehnese, since the prefix registers specific person and politeness features of the implicit agent, not reduced or default features as would be expected of agreement with $\mathrm{PRO}_{A R B}$.

${ }^{39}$ This possibility was noted in 4 above. For discussion of other languages in which the grammatical subject position may be left empty, see inter alia McCloskey 1996, Alexiadou \& Anagnostopoulou 1998, Doron 2000, Roberts 2005, Cable 2012.

${ }^{40}$ These arguments equally rule out a clitic doubling analysis. A clitic in the absence of an associated DP would be interpreted as pronominal, and the scope of a DP related to a clitic is at least as high as the clitic. In addition, a clitic doubling analysis would not allow for the possibility of an indefinite linked to the prefix, as in the following.
}

(i) Aneuk miet nyan hana ji-kap lé sa peue pih. child small DEM NEG 3.FAM-bite by one what even 'The child wasn't bitten by anything.'

(ii) Aneuk miet nyan hana ji-kap lé beurang-ka-peue. child small DEM NEG 3.FAM-bite by any-PRT-what 'The child wasn't bitten by anything.' 
external argument position, specifying that it bears an INITIATOR $\theta$-role,${ }^{41}$ bears thirdperson features, and is of a rank higher than the speaker. More formally, Chung and Ladusaw (2004) propose two modes of semantic combination: (i) SATURATION satisfies the argument position through function application or existential closure, and (ii) PREDICATE RESTRICTION modifies the argument position, which must then be satisfied either through function application or quantificational binding. As an example of predicate restriction, they provide object incorporation in Chamorro. ${ }^{42}$ In 72 , 'pet' restricts the object position of 'have', and then the object position is saturated by 'cat'.

(72) Gäi-ga' yu' kätu, lao matai.

AGR.have-pet I cat but AGR.die

'I had a pet cat, but it died.'

(Chung \& Ladusaw 2004:76)

From this perspective, the Acehnese prefix can be understood as an instance of predicate restriction applying internally to the $v$ head. Just as 'pet' restricts the object position in 72 , 'third person of lower rank than speaker' restricts the subject position in $73 .{ }^{43}$

(73) a. Uleue nyan di-kap lôn. snake DEM 3.FAM-bite $1 \mathrm{SG}$

'The snake bit me.'

b. Lôn di-kap lé uleue nyan.

1SG 3.FAM-bite by snake DEM

'I was bitten by the snake.'

Subsequent to predicate modification, in 73a, the external argument position is saturated by 'that snake', while in $73 \mathrm{~b}$, the position is existentially bound. ${ }^{44}$

This analysis successfully explains the core properties of the prefix. It appears in the passive, and in the active with transitive and unergative but not unaccusative predicates, because these are the predicates that include an external argument introducing $v$. It appears low in the tree, at the high edge of the verb phrase, because it realizes $v$. It tracks the features of the thematic subject, rather than the surface subject, because its features semantically restrict the thematic subject position, rather than being semantically uninterpretable agreement. The explanation of these properties is achieved without adding additional syntactic or semantic machinery. All of the elements of the analysis - $\phi$-features, an external argument introducing functional projection $v$, and the predicate restriction mode of composition - are independently required. What makes Acehnese unusual is simply the particular combination of these three elements. ${ }^{45}$

For discussion of clitic doubling, see, for example, Suñer 1988, Uriagereka 1988, 1995, Sportiche 1996, 1998, Anagnostopoulou 2003.

${ }^{41}$ I use Initiator as an inclusive $\theta$-role that abstracts away from the thematic distinctions among external arguments, following, for example, Ramchand 2008. See also Baker (1997), who argued for only three coarse-grained syntactic $\theta$-roles, and Hale and Keyser's (2002) related reduction of $\theta$-roles to syntactic configurations.

42 For related work on the semantics of incorporation and pseudo-incorporation, see, for example, van Geenhoven 1998 and Dayal 2010.

${ }^{43}$ And the title restricts the subject position in 64 . The association of second-person features with the title is achieved for Acehnese in whatever manner it is achieved for the other languages cited.

${ }^{44}$ More precisely, there are two $v$ s, an active and a passive. Both introduce an Initiator $\theta$-role and include features that restrict the Initiator; they differ in that the passive existentially binds the Initiator. The $b y$-phrase is licensed by the passive $v$, and incorporated into the structure by tying it to the event argument of the verb. See Legate 2011a for details; also related is Bruening 2013.

45 One may wonder whether any other language has restrictive $\phi$-features. In Legate 2010a, I proposed that the Chamorro passive morpheme does as well. In Chamorro, implicit agents must be third person, and the passive morpheme $m a$ - is used for plural (implicit) agents, whereas -in- is used for singular (see e.g. Topping \& Dungca 1973, Cooreman 1987, Chung 1998, 2004 for discussion). 
It is instructive to compare the proposed analysis of the Acehnese prefix with the analysis of Perlmutter 1982. Perlmutter (working within the RELATIONAL GRAMMAR framework) proposes the following. ${ }^{46}$

(74) Verb agreement in Achenese: The verb of a clause $b$ agrees with the initial 1 of the clause.

Here the INITIAL 1 is a noun phrase that bears the subject grammatical function at an initial stage in the derivation. He takes this agreement in Acehnese as a strong argument for the necessity of an initial 1 , and thus for a demotion analysis of the passive and for the unergative/unaccusative distinction. The proposal developed here adopts significant elements of the analysis he advocates. The three-way distinction between an initial subject position (now identified with the specifier of $v \mathrm{P}$ ), a surface subject position (now identified with the specifier of IP), and the initial object position are now standard, as is the unergative/unaccusative distinction. The demotion analysis of the passive, however, is of a different nature on the framework assumed here, in that the relationship between a subject and an adjunct cannot be simply captured through base-generation and upward movement. The proposal here avoids these issues by identifying the agreement with the functional head that introduces the external argument, rather than agreement triggered by the argument itself. Perlmutter argues against a thematic analysis of the Acehnese agreement, for example one in which the verb agrees with the agent of the clause, noting that initial subjects of different $\theta$-roles all trigger the agreement. A few of his examples follow. ${ }^{47}$ The first two illustrate agreement triggered by a nonagent; the second two illustrate a recipient subject triggering agreement, but not a recipient object.

(75) a. Bubông nyan ji-tumpang lé taméh. roof DEM 3.FAM-support by column

'The roof is supported by columns.'

b. Lôn ji-peu-ingat gadoh gopnyan lé haba.

1SG 3.FAM-CAUS-remember lost 3.POL by story

'I was reminded of his disappearance by a message.' (Perlmutter 1982:330)

c. Gopnyan geu-teurimong surat.

3.POL 3.POL-receive letter

'He received a letter.'

d. Gopnyan ka geu-bri buku nyan keu kamoe. 3.POL PERF 3.POL-give book DEM to 1.EXCL

'He gave a book to us.' (Perlmutter 1982:331) This argument does not impact the current proposal. Although the prefix realizes the features of the head that introduces the external argument, there is no relationship posited between the prefix and any particular $\theta$-role. All and only those DPs that are

(i) a. Kao pära infan-k<in>enni' na tres pära $\mathrm{i}$ sho?

Q FUT 2PL.INTRANSSUBJ-take $<$ PASS.3 $>\mathrm{L}$ three to the show

'Are the three of you going to be taken to the movies (by him)?' (Chung 1998:37)

b. Guäha na biahi nai ma-usa ädyu na palabra ni manamku'. AGR.exist L time C PASs.3PL-use that $\mathrm{L}$ word OBL old.ones

'There are times when those words are used by adults.'

This pattern is explained if the passive $v$ morpheme $m a$ - has restrictive third-person plural features, while $-i n$ has restrictive third-person (singular).

Also related is Wiltschko 2008, which argues that the plural in Halkomelem Salish is an adjunct, modifying category-neutral roots.

${ }^{46}$ Perlmutter follows Lawler's spelling of Acehnese as 'Achenese'.

${ }^{47}$ Spelling has been standardized and glosses added. 
external arguments will be accompanied by the prefix, ${ }^{48}$ regardless of their thematic interpretation. ${ }^{49}$

6. ConClusions. In this article, I have demonstrated that Acehnese has a passive in which a verbal prefix bears person and politeness features of the (implicit) agent. The same prefix in the active bears person and politeness features of the external argument. I have developed an analysis whereby the prefix realizes interpretable features of the functional head that introduces the external argument. These features restrict, but do not saturate, the external argument position. Acehnese understood in this way clearly demonstrates the existence in the passive of the functional head that introduces the external argument. I have also demonstrated that Acehnese exhibits evidence of a grammatical subject position; thus, the language should no longer be cited as evidence that grammatical functions are not universal.

\section{REFERENCES}

Adger, David, and Gillian Ramchand. 2007. Psych nouns and the structure of predication. North East Linguistic Society (NELS) 36.89-102.

ALDRIDGE, EDITH. 2002. WH-movement in Seediq and Tagalog. MIT Working Papers in Linguistics (Proceedings of the eighth annual meeting of the Austronesian Formal Linguistics Association (AFLA 8)) 4.1-28.

AldRIDGE, EDITH. 2008. Phase-based account of extraction in Indonesian. Lingua 118. $1440-69$.

Alexiadou, Artemis, and Elena Anagnostopoulou. 1998. Parameterizing AGR: Word order, V-movement and EPP-checking. Natural Language and Linguistic Theory 16. 491-539.

Alexiadou, Artemis; Elena Anagnostopoulou; and Florian Schäfer. 2006. The properties of anticausatives crosslinguistically. Phases of interpretation, ed. by Mara Frascarelli, 187-211. Berlin: Mouton de Gruyter.

Anagnostopoulou, Elena. 2003. The syntax of ditransitives: Evidence from clitics. Berlin: Mouton de Gruyter.

ARKA, I WAYAN, and Christopher D. MANNING. 1998. Voice and grammatical relations in Indonesian: A new perspective. Proceedings of the $L F G$ '98 Conference. Online: http:// csli-publications.stanford.edu/LFG/3/arka-manning.html.

AsYiK, ABdul Gani. 1982. The agreement system in Acehnese. Mon-Khmer Studies 11.133.

AsyiK, ABDUl GANI. 1987. A contextual grammar of Acehnese sentences. Ann Arbor: University of Michigan dissertation.

BAKER, MARK. 1985. The mirror principle and morphosyntactic explanation. Linguistic Inquiry $16.373-415$.

BAKER, MARK. 1997. Thematic roles and syntactic structure. Elements of grammar, ed. by Liliane Haegeman, 73-137. Dordrecht: Kluwer.

BéJar, Susana, and Milan Rezac. 2009. Cyclic Agree. Linguistic Inquiry 40.35-73.

BENINCÀ, PAOLA. 2001. The position of topic and focus in the left periphery. Current studies in Italian syntax: Essays offered to Lorenzo Renzi, ed. by Guglielmo Cinque and Giampaolo Salvi, 39-64. Amsterdam: Elsevier-North Holland.

BenincÀ, Paola, and Cecilia Poletto. 2004. Topic, focus and V2: Defining the CP sublayers. The structure of $C P$ and IP, ed. by Luigi Rizzi, 52-75. Oxford: Oxford University Press.

BittNer, Maria, and Ken Hale. 1996. The structural determination of case and agreement. Linguistic Inquiry 27.1-68.

Bruening, Benjamin. 2013. By-phrases in passives and nominals. Syntax, to appear.

\footnotetext{
${ }^{48}$ In the active and passive; as mentioned above, the object voice morpheme is uniformly null.

49 A referee correctly points out that Perlmutter's argument also does not impact a thematic agreement analysis that also employs a coarse-grained Initiator $\theta$-role.
} 
BÜRING, DANIEL. 2004. Crossover situations. Natural Language Semantics 12.23-62.

Cable, Seth. 2012. The optionality of movement and EPP in Dholuo. Natural Language and Linguistic Theory 30.651-97.

CARdinaletti, AnNa, and Ur Shlonsky. 2004. Clitic positions and restructuring in Italian. Linguistic Inquiry 35.519-57.

ChOMSKY, NoAm. 1995. The minimalist program. Cambridge, MA: MIT Press.

CHOMsky, NoAm. 2000. Minimalist inquiries: The framework. Step by step: Essays on minimalist syntax in honor of Howard Lasnik, ed. by Roger Martin, David Michaels, and Juan Uriagereka, 89-155. Cambridge, MA: MIT Press.

Chomsky, Noam. 2008. On phases. Foundational issues in linguistic theory, ed. by Robert Freidin, Carlos P. Otero, and Maria Luisa Zubizarreta, 133-66. Cambridge, MA: MIT Press.

Chung, Sandra. 1976. On the subject of two passives in Indonesian. Subject and topic, ed. by Charles N. Li, 57-98. New York: Academic Press.

Chung, SANDRA. 1978. Stem sentences in Indonesian. Second International Conference on Austronesian Linguistics: Proceedings, fascicle 1, Western Austronesian (Pacific linguistics C-61), ed. by S. A. Wurm and Lois Carrington, 335-65. Canberra: Australian National University.

Chung, SAndra. 1998. The design of agreement. Chicago: University of Chicago Press.

Chung, SANDRA. 2004. Restructuring and verb-initial order in Chamorro. Syntax 7.199233.

Chung, Sandra, and William Ladusaw. 2004. Restriction and saturation. Cambridge, MA: MIT Press.

Cinque, Guglielmo. 2004. 'Restructuring' and functional structure. Structures and beyond, ed. by Adriana Belletti, 132-91. New York: Oxford University Press.

Cole, Peter, and Gabriella Hermon. 1998. The typology of wh-movement: Wh-questions in Malay. Syntax 1.221-58.

Cole, Peter; Gabriella Hermon; and Yanti. 2008. Voice in Malay/Indonesian. Lingua $118.1500-1553$.

Collins, Chris. 2005. A smuggling approach to the passive in English. Syntax 8.81-120.

CoOREMAn, AnN M. 1987. Transitivity and discourse continuity in Chamorro narratives. New York: Mouton de Gruyter.

Corbett, Greville G. 1991. Gender. Cambridge: Cambridge University Press.

Corbett, Greville G. 2000. Number. Cambridge: Cambridge University Press.

Corbett, Greville G. 2006. Agreement. Cambridge: Cambridge University Press.

CowAN, H. K. J. 1981. An outline of Achehnese phonology and morphology. Bulletin of the School of Oriental and African Studies 44.522-49.

Cuervo, María Cristina. 2003. Datives at large. Cambridge, MA: MIT dissertation.

Daud, BuKhari, and Mark Durie. 1999. Kamus Basa Acèh: Kamus Bahasa Aceh: Acehnese-Indonesian-English thesaurus. Melbourne: Pacific Linguistics.

Dayal, VeneEta. 2010. Hindi pseudo incorporation. Natural Language and Linguistic Theory $29.123-67$.

Dixon, R. M. W. 1994. Ergativity. Cambridge: Cambridge University Press.

Doron, EDIT. 2000. VSO and left-conjunct agreement: Biblical Hebrew vs. Modern Hebrew. The syntax of verb initial languages, ed. by Andrew Carnie and Eithne Guilfoyle, 75-96. Oxford: Oxford University Press.

DRYer, MATTHEW. 1986. Primary objects, secondary objects and antidative. Language $62.808-45$.

DURIE, MARK. 1985. A grammar of Acehnese on the basis of a dialect of North Aceh. Dordrecht: Foris.

DuRIE, MARK. 1987. Grammatical relations in Acehnese. Studies in Language 11.387-421.

DURIE, MARK. 1988. The so-called passive of Acehnese. Language 64.104-13.

EMBICK, DAVID. 2004. On the structure of resultative participles in English. Linguistic Inquiry 35.355-92.

Foldi, RafFaella, and Heidi Harley. 2004. Flavors of $v$ : Consuming results in Italian and English. Aspectual inquiries, ed. by Roumyana Slabakova and Paula Kempchinsky, 95-120. Dordrecht: Kluwer.

FoX, DANNY. 1999. Reconstruction, binding theory and the interpretation of chains. Linguistic Inquiry 30.157-96. 
Goddard, ClifF. 2005. The languages of East and Southeast Asia: An introduction. Oxford: Oxford University Press.

Guilfoyle, Eithne; HenRiETTA Hung; and Lisa Travis. 1992. SPEC of IP and SPEC of VP: Two subjects in Austronesian languages. Natural Language and Linguistic Theory $10.375-414$.

Haegeman, LiLiane, and HenK Van RiemsdiJK. 1986. Verb projection raising, scope, and the typology of rules affecting verbs. Linguistic Inquiry 17.417-66.

Hale, Kenneth, and Samuel J. Keyser. 2002. Prolegomena to a theory of argument structure. Cambridge, MA: MIT Press.

Harbour, Daniel; David Adger; and Susana BéJar (eds.) 2008. Phi theory-Phi-features across modules and interfaces. Oxford: Oxford University Press.

HaRLEY, HeIDI. 2008. The bipartite structure of verbs cross-linguistically, or, Why Mary can't exhibit John her paintings. Conferências do V Congresso Internacional da Associação Brasileira de Lingüística, ed. by Thaïs Cristófaro Silva and Heliana Mello, 45-84. Belo Horizonte: ABRALIN and FALE/UFMG.

HARLEY, HEIDI. 2013. External arguments and the mirror principle: On the independence of Voice and $v$. Lingua, to appear.

KAYNE, RICHARD. 1991. Romance clitics, verb movement, and PRO. Linguistic Inquiry $22.647-86$

Kenesei, István; Robert Michael Vágó; and Anna Fenyvesi. 1998. Hungarian. New York: Routledge.

Ko, Seongyeon. 2008. Causative alternation and voice morphology in Acehnese. Paper presented at the annual meeting of the Linguistic Society of America, Chicago.

KoH, Ann Sweesun. 1990. Topics in colloquial Malay. Melbourne: University of Melbourne dissertation.

Kratzer, AngeliKa. 1996. Severing the external argument from its verb. In Rooryck \& Zaring, 109-37.

LANDAU, IDAN. 2004. The scale of finiteness and the calculus of control. Natural Language and Linguistic Theory 22.811-77.

LANDAU, IDAN. 2009. Saturation and reification in adjectival diathesis. Journal of Linguistics 45.315-61.

LASNIK, HowARD, and TIM STOWell. 1991. Weakest crossover. Linguistic Inquiry 22.687720.

LAWLeR, JoHn M. 1977. A agrees with B in Achenese: A problem for relational grammar. Grammatical relations, ed. by Peter Cole and Jerrold M. Sadock, 219-48. New York: Academic Press.

LAWLER, JOHN M. 1988. On the questions of Acehnese 'passive'. Language 64.114-17.

LeBeAuX, DaVID. 1995. Where does the binding theory apply? Technical report 98-044. Princeton, NJ: NEC Research Institute.

Legate, Julie AnNe. 2010a. Not-so-implicit agents. Paper presented at the 17th meeting of the Austronesian Formal Linguistics Association (AFLA), Stony Brook University.

Legate, Julie AnNe. 2010b. The structure of implicit agents in passives. Paper presented at the 40th meeting of the North East Linguistic Society (NELS), Cornell University.

Legate, Julie AnNe. 2011a. VoiceP: Lessons from Acehnese. Linguistics colloquium talk, Georgetown University, Washington, DC.

Legate, Julie AnNe. 2011b. Under-inheritance. Paper presented at the 41st meeting of the North East Linguistic Society (NELS), University of Pennsylvania.

Legate, Julie AnNe. 2011c. Passive agreement in Acehnese. North East Linguistic Society (NELS) 39.505-15.

MANNIng, Christopher D. 1996. Ergativity: Argument structure and grammatical relations. Stanford, CA: CSLI Publications.

Marantz, Alec. 2001. Words. Paper presented at the 20th West Coast Conference on Formal Linguistics (WCCFL), University of Southern California.

Massam, Diane. 2003. Questions and the left periphery in Niuean. Cornell Working Papers in Linguistics (Proceedings of the ninth annual meeting of the Austronesian Formal Linguistics Association (AFLA 9)) 19.94-106.

McCloskey, James. 1996. Subjects and subject positions in Irish. The syntax of the Celtic languages: A comparative perspective, ed. by Robert D. Borsley and Ian Roberts, 241-83. Cambridge: Cambridge University Press. 
MCGinNis, MaRTHA. 2001. Variation in the phase structure of applicatives. Linguistic Variation Yearbook 1.105-46.

MiYAGAWA, SHIGERU. 1987. Restructuring in Japanese. Issues in Japanese linguistics, ed. by Takashi Imai and Mamoru Saito, 273-300. Dordrecht: Foris.

NeWMEYER, Frederick J. 2002. Optimality and functionality: A critique of functionallybased optimality-theoretic syntax. Natural Language and Linguistic Theory 20.43-80.

Paul, Ileana. 2001. Concealed pseudo-clefts. Lingua 111.707-27.

Perlmutter, David M. 1982. Syntactic representation, syntactic levels, and the notion of subject. The nature of syntactic representation, ed. by Pauline Jacobson and Geoffrey K. Pullum, 283-340. Dordrecht: Reidel.

Pearson, Matthew. 2001. The clause structure of Malagasy: A minimalist approach. Los Angeles: University of California, Los Angeles dissertation.

Postal, PAul. 1993. Remarks on weak crossover. Linguistic Inquiry 24.539-56.

POTSDAM, ERIC. 2006. More concealed pseudoclefts in Malagasy and the clausal typing hypothesis. Lingua 116.2154-82.

PotSDAM, ERIC. 2009. Austronesian verb-initial languages and WH-question strategies. Natural Language and Linguistic Theory 27.737-71.

PYLKKÄNEN, LIINA. 1999. Causation and external arguments. MIT Working Papers in Linguistics (Papers from the UPenn/MIT Roundtable on the Lexicon) 35.161-83.

PYLKKÄNEN, LINNA. 2008. Introducing arguments. Cambridge, MA: MIT Press.

Ramchand, Gillian Catriona. 2008. Verb meaning and the lexicon: A first-phase syntax. Cambridge: Cambridge University Press.

ReINHART, TANYA. 1983. Anaphora and semantic interpretation. London: Croom Helm.

RIZzI, LuIGI. 1997. The fine structure of the left periphery. Elements of grammar: A handbook of generative syntax, ed. by Liliane Haegeman, 281-337. Dordrecht: Kluwer.

RIZZI, LuIGI. 1982. Issues in Italian syntax. Dordrecht: Foris.

ROBERTS, IAN. 1997. Restructuring, head movement, and locality. Linguistic Inquiry 28. 423-60.

RoBerts, IAn. 2005. Principles and parameters in a VSO language: A case study in Welsh. Oxford: Oxford University Press.

RoORYCK, Johan, and LAURIE ZARING. 1996. Phrase structure and the lexicon. Dordrecht: Kluwer.

RUYS, EDDY G. 2000. Weak crossover as a scope phenomenon. Linguistic Inquiry 31.51339.

RUYS, EDDY G. 2004. A note on weakest crossover. Linguistic Inquiry 35.124-40.

SAto, Yosuke. 2012. Successive cyclicity at the syntax-morphology interface: Evidence from Standard Indonesian and Kendal Javanese. Studia Linguistica 66.32-57.

SCHÄFER, Florian. 2008. The syntax of (anti-)causatives. Amsterdam: John Benjamins.

Serratos, Angelina Eduardovna. 2008. Topics in Chemehuevi morphosyntax: Lexical categories, predication and causation. Tucson: University of Arizona dissertation.

Siewierska, AnNa. 2004. Person. Cambridge: Cambridge University Press.

SNeddon, James NeIL. 1996. Indonesian: A comprehensive grammar. London: Routledge.

Song, JAE Jung (ed.) 2011. The Oxford handbook of linguistic typology. Oxford: Oxford University Press.

Sportiche, Dominique. 1992. Clitics, voice and spec-head licensing. GLOW Newsletter $28.46-47$.

SPORTICHE, DOMINIQUE. 1996. Clitic constructions. In Rooryck \& Zaring, 213-76.

Sportiche, DominiQue. 1998. Partitions and atoms of clause structure: Subjects, agreement, case and clitics. London: Routledge.

Sportiche, Dominique. 2011. The van Riemsdijk-Williams puzzle: In de Fourier's footsteps. Paper presented at Parallel Domains: A workshop in honor of the work of JeanRoger Vergnaud, Los Angeles.

Suñer, Margarita. 1988. The role of agreement in clitic-doubled constructions. Natural Language and Linguistic Theory 6.391-434.

Svenonius, Peter. 2001. Case and event structure. ZAS Working Papers in Linguistics 26. $1-21$.

Tomasello, Michael. 1995. Language is not an instinct. Cognitive Development 10.13156.

Topping, Donald M., and Bernadita C. DungCA. 1973. Chamorro reference grammar. Honolulu: University of Hawaii Press. 
TRAVIS, LisA. 2000. The L-syntax/S-syntax boundary: Evidence from Austronesian. Formal issues in Austronesian linguistics, ed. by Ileana Paul, Vivianne Phillips, and Lisa Travis, 167-94. Dordrecht: Kluwer.

Travis, LISA. 2005. Agents and causes in Malagasy and Tagalog. The syntax of aspect: Deriving thematic and aspectual information, ed. by Nomi Erteschik-Shir and Tova Rapoport, 174-89. New York: Oxford University Press.

Tubino Blanco, Mercedes. 2010. Contrasting causatives: A minimalist approach. Tucson: University of Arizona dissertation.

URIAGEREKA, JUAN. 1988. On government. Storrs: University of Connecticut dissertation.

UriagereKa, Juan. 1995. Aspects of the syntax of clitic placement in Western Romance. Linguistic Inquiry 26.79-124.

VAn Geenhoven, Veerle. 1998. Semantic incorporation and indefinite descriptions: Semantic and syntactic aspects of noun incorporation in West Greenlandic. Stanford, CA: CSLI Publications.

Van Valin, Robert D., and Randy J. LaPolla. 1997. Syntax: Structure, meaning and function. Cambridge: Cambridge University Press.

Wallace, StePhen. 1983. Pronouns in contact. Essays in honor of Charles F. Hockett, ed. by Frederic B. Agard, Gerald Kelley, Adam Makkai, and Valerie Becker Makkai, 57389. Leiden: E. J. Brill.

WiltschKo, Martina. 2008. The syntax of non-inflectional plural marking. Natural Language and Linguistic Theory 26.639-94.

WOLFF, JOHN. 1996. The development of the passive verb with pronominal prefix in western Austronesian languages. Reconstruction, classification, description: Festschrift in honor of Isidore Dyen, ed. by Bernd Nothofer, 15-40. Hamburg: Abera.

WURMBRAND, SusI. 2001. Infinitives: Restructuring and clause structure. Berlin: Mouton de Gruyter.

610 Williams Hall

[Received 8 June 2011;

Department of Linguistics

accepted 13 February 2012]

University of Pennsylvania

$255 \mathrm{~S} 36$ th St

Philadelphia, PA 19104

[jlegate@ling.upenn.edu] 